\title{
Defying the Dominant Masculine Identity in D. H. Lawrence's Novel The Rainbow
}

\author{
Angelina Subrayan (Corresponding author) \\ Faculty of Modern Languages and Communication, Universiti Putra Malaysia, 43400 UPM Serdang, Selangor, Malaysia \\ E-mail: angiesubrayan@hotmail.com \\ Wan Roselezam Wan Yahya \\ Department of English, Faculty of Modern Languages and Communication, Universiti Putra Malaysia, 43400 UPM, Serdang, Selangor, Malaysia \\ E-mail: roselezam@upm.edu.my
}

Received: 14-04-2016

Published: 01-09-2016
Accepted: 26-06-2016

doi:10.7575/aiac.ijalel.v.5n.5p.179
Advance Access Published: July 2016

URL: http://dx.doi.org/10.7575/aiac.ijalel.v.5n.5p.179

\begin{abstract}
The active contributions to studies on men and masculinity that comprise a wide scope of cultures support the notion that significant social organisations legitimise the domination of men over women. Men's dominance over women is ideologically sanctioned in some cultures. However, not all men observe this nature of masculinity as there are some who dispute the dominant type of masculinity by inculcating alternative masculinities which are subordinate in nature. Nevertheless, most men place themselves fittingly in unavoidable circumstances especially in gendered relationships. In this study, there are instances in D.H. Lawrence's novel, The Rainbow that show how one of the male protagonists rebels against the social convention that advocates stereotyped masculine norm. The purpose of this study is to explicate the male protagonist's portrayal of subordinate masculinity that flouts the social expectations during the industrial British era. This study applies the concept of Wetherell and Edley to explicate the features associated with subordinate masculinity in a gendered relationship. The fundamental findings reveal that the male protagonist negotiates his dominant masculinity to allow improved relationship with his spouse.
\end{abstract}

Keywords: Masculinity, Dominant, Subordinate, Defying, Gendered relationship

\section{Introduction}

Studies on masculinity have discussed how the concept of masculinity has transformed in recent times. Lawrence in his work Fantasia of the Unconscious (1971), revealed that the difference between men and women in the areas of education and marriage is obviously caused by the belief that men are grounded logically on the principle that they are more advanced than women and any changes in this situation will obviously be unsuccessful. In fact, in a patriarchal society, the cultural ideas about an ideal masculinity are tools of social control that are used to maintain patriarchal order (Johnson 85-86). The adjustment from the gender history of masculinity to the history of masculinities is basically caused by Tosh's idea of 'the fruitful enquiries of historians' (14-15). During the mainstream of the eighteenth century, the theory of masculinity was interwoven with external politeness and improvement (Carter 1). Since Lawrence's fundamental concern in most part of his work is about the relationship between men and women, it justifies the attempt made to study his novel through the point of view of one of the male protagonists through his relationship with his spouse. The rapport between the opposing genders and the characters' position in society are what matters most to Lawrence.

The period of industrialisation and the effect of World War 1 in the novel observed the momentary experience in social, economic, and individual growth. It was also a time of voyage, a battlefield for the conflict on science and religion. However, more important to these powerful signs is the industrial revolution's reign that encouraged adjustment within an individual's character, which is a redefinition of what it means to be a human. It is this rising consciousness of difference that appears to promote most men, the feelings of loneliness, misery, alienation and all the noticeable themes in the early twentieth century writings. During this time, men were trapped by the heartless inhuman industrial system. Negotiation on the portrayal of masculinity was crucial to reduce constraints experience by these men. Through careful reading of the novels, there is evidence in Lawrence's masculine perspectives that illustrates conflicts of identities when Tom Brangwen, the male protagonist defies the dominant type of masculinity. Most importantly, "one of the most successful ways of being hegemonic, or being a 'man' could be to exhibit one's detachment from the dominant form of masculinity as a way of supporting gender equality” (Wetherell and Edley 351).

\section{Methodology}

Wetherell and Edley (1999) in their study, worked on an unconventional vital discursive psychology of masculinity. They worked intensely with the idea of how men position themselves in connection to traditional ideas of being men. 
They indicated that, there is a need to consider the likelihood that complicity and resistance to the dominant type of masculinity can be combined. In addition, Wetherell and Edley assert that men position themselves in diverse ways at different times. They discovered that men have a tendency to take discursive routes while formulating negotiating positions of masculinity (335).

In the present study, the focus is on the male protagonist's nonconformity to dominant masculinity to pursue a more egalitarian rapport with his wife. The Rebellious type of masculine behaviours requires the male character to define himself with regards to his nonconformity, and the negotiations comprise the flouting of social expectations. Men who are dominant in the beginning may cast-off their authoritarian macho masculinity and behave in contrast to being manly and may become domesticated. The critical examination in this study is based on the perception where, it is likely, that men detached themselves from dominant forms of masculinity to sustain gender equality. Relevant excerpts are collected from the novel to illuminate how the dominant portrayal of masculinity is defied by the male protagonist.

\section{Analysis and discussion}

The act of responding to the variations in society's concepts of masculinity and femininity and most importantly the condition of marriage, has forced Lawrence's male protagonist Tom to establish a new world. This is done in his understanding of a prevailing pattern through his notions of masculine roles. Tom does not maintain only one feature throughout the novel. He either negotiates his dominant self to have a balanced relationship with his spouse or intends to seek contentment in his life.

3.1 Summary of the Novel

The Rainbow narrates the story of the Brangwen family, who ploughed in the Midlands of England, from around 1840 to 1900. Tom from the first generation weds Lydia Lensky (Lydia), who is a Polish widow. Tom finds comfort in adjusting to life in his farm and lives with an old woman who is the housekeeper. He meets a Polish widow, who has a daughter from her previous marriage. Tom proposes to her and they get married.

\section{2 The Character Tom in the Novel}

Tom Brangwen is a significant English farmer who is a lonesome masculine bachelor. His life is focused on his yearnings for sordid relationships with unfamiliar women and to frequent bouts with alcohol until one day quite abruptly he marries Lydia Lensky, a Polish widow. While he occasionally desires for an exterior life from the intimate world of the Marsh Farm, he knows that he is only suitable in his world. Like all the Brangwen men, he attempts to exert his determination over his wife, but he is not as unrelenting as the other Brangwens in the novel. Eventually, his kindness and patience gain Lydia's trust, and the two discover contentment in their marriage.

\subsection{Defying Dominant Masculinity}

We get to see Tom, who totally rejects the dominant form of masculinity in a number of incidents in the novel. In the beginning of the novel, we see Tom struggling to adapt to ideas that his mother wants from him including in his studies. He constructs the idea that "He could not learn deliberately . . . so he had a low opinion of himself. He knew his own limitations" (The Rainbow 17). These feelings of low self-esteem are due to the incompetency that pervades every aspect of his life. Lawrence depicts Tom, who is the main character of the Brangwens to experience "fragmentary, something incomplete and subject" (40). Tom avoids effort to battle these mindsets, but rather attempts to numb these feelings with alcohol. He did not have the power to challenge even the smallest argument and felt that he was required to concede to issues that he did not in the least believe in. And having acknowledged them, he did not discern whether he believed them or "he rather thought he did" (17). Tom's incapability to grasp the tasks given by his mother impairs Tom's sense of self-respect. In his initial and deepest childhood acquaintance with a "warm, clever boy" (19), Tom perceives himself to be the "server" in their bonding since he "never felt equal with his friend, because the other's mind outpaced his own" (19). This idea of pleasing another person and fulfilling their anticipations and requirements including the circumstance leading to the deeds that are required to do so are emotionally excruciating for Tom.

As the critic Gavriel Ben-Ephraim (1981) states, "Molded by women, Tom lacks confident maleness, let alone assertive sexuality. The over influence of women in his formation leads to a deficiency not only of manhood but of being. Tom relies on women for his 'stability'. .." (134). Even though Tom has problems having sexual or romantic link with women, he nonetheless frantically needs a wife. He appears to imagine that marriage is the only solution to his experience of solitude and desolation as "he wanted something to get hold of, to pull himself out. But there was nothing" (26). Tom fails to find a woman to "get a hold of", and so he indulged in drinking. Alcohol offers him with "this kindled state of oneness with all the world .... obliterating his own individuality, that which it depended on his manhood to preserve and develop" (28). For Tom, peace is to have a lasting relationship with a woman. Clearly, Tom believes that he must be able to lose himself in woman. This aspiration is paradoxical because while Tom longs to lose himself in another, he also greatly fears this self-destruction in the form of submissive masculinity.

Lydia's distant attitude makes Tom sense that there is hope for his masculine identity and so he trails her passionately to cling to the feeling that:

He must admit that he was only fragmentary, something incomplete and subject . . he sat small and submissive to the greater ordering . . .. He was nothing. But with her, he would be real.... she would bring him completeness and perfection. (40) 
Tom's relationship with his wife is indicative of a mother and child relationship. Tom has a deep need to have Lydia recognise him as a man and as her husband in an unspecified way. He does not know how their relationship should proceed, or what his place in it is for, "he did not feel like a master, husband, father of her children" (58). Although Tom and Lydia do ultimately understand each another, Tom remains struggling with his thoughts of destruction and masculine inadequacy.

Since Tom's masculine idealness has been tormented by his experience of having been "let down" by his mother, he allocates his requirement for idealised "recognition" to Lydia, thus creating her to be the idealised character on whom he depends. Being a man, it should be Tom who should be idealised and not the other way round. Here, Tom is resisting the dominant masculinity. However, Lydia does not allow this type of relationship with Tom. During one of their arguments, Lydia proclaims to Tom, "You [you] come to me as if it were for nothing, as if I was nothing there," to which Tom responds, "You [you] make me feel as if $I$ was nothing" (89). Unlike Tom, Lydia does not want to be portrayed as an ideal person to him and neither does she want him to be dependent on her. Lydia prefers a relationship which depicts partnership with equal rights. Tom allows himself to be manipulated implicitly by Lydia's decision. Subjectivity is applied here when Tom's decision to resist the dominant masculinity is based on his own opinion and understanding.

In another scene, as the birth of their child draws nearer, Lydia is overwhelmed with the memories of her late children and her previous husband. Instead of displaying anger that Lydia is reminiscing about her past, Tom accepts the truth that "he must stand back, leave her alone .... This is sacred to her, and he must not violate her with his comfort" (63). The circumstance that has drawn Lawrence to create Tom to come to this understanding on the same page is that Tom confesses to feeling "like a broken arch" but has "remained himself...saved himself from crashing down into nothingness, from being squandered into fragments, by sheer tension" (63) is noteworthy. It is clearly manifested that Tom resists his dominant identity to acknowledge his own separation through his wife's "rejection" of him. Later, when Lydia lies in childbirth, crying in pain, Tom acknowledges and accepts that the pain is his own pain too. He also reacts to and accepts the emotional agony of Lydia's young daughter, Anna, who is weary, alarmed, and longing for her mother's company. Tom not only acknowledges Anna who is missing her mother, but he effectively calms her, which marks the starting of a convincing bond between a father and a child. These are essential phases in Tom's life where he resists his dominant masculine character. He portrays his subordinate nature to dominance as his subjective decision allows him to think rationally for himself, and decide what is the practical thing to do as a husband and as a father.

Tom longs for a life of classiness and prosperity similar to his wealthy brother and he detests his underprivileged life. It was after two years of marriage that he and Lydia realised each other's desire for unity. The fundamental key to a happy accomplishing marriage was to restructure each other's attitude with equality, and that resulted in having a wonderful life and each day was a new breakthrough:

They had passed through the doorway into the further space, where movement was so big, that it contained bonds and constraints and labour, and still was complete liberty. She was the doorway to him, he to her. At last they had thrown open the doors, each to the other, and had stood in the doorways facing each other, it was the transfiguration, glorification, the admission. (41)

Tom perceives Lydia not as her true self but relatively as an ideal to be worshipped. In his adoration, he anticipates in some way to make peace with her. He "knew she was his woman, he knew her essence, that it was his to possess" (58), but he could not actually acquire her, which results in his core defeat. Tom is placing his resistance when this emphasis is focused on his own idea, feeling and attitude. They sat down to discuss their problem, thus breaking the leading patriarchal social practice. As a result of Tom and Lydia coming together in a harmonious way, their daughter Anna was at peace between them.

In one of the episodes with Lydia's child Anna, Lawrence exhibits Tom's personal connection with maternal nurturing evidences: "[He] discovers the maternal within himself and assumes the role of tender, soothing nurturer" (83). This creates a scene that is emotional and decisive as Tom's evolvement has construct to become the contributor of comfort rather than the patriarchal dominant figure. This act proves to show that Tom is defying the dominant type of masculinity.

Tom permitted Lydia space and safeguarded her individuality, therefore she is eternally thankful to him. The discussion clearly shows that the formation of a fresh relation, or the modification of the previous one, between men and women with unity is vital to have a positive relationship in marriage. In his Study of Thomas Hardy (1914), Lawrence writes, of the archetypal man:

Let a man walk alone on the face of the earth, and he feels himself like a loose speck blown at random. Let him have a woman to whom he belongs, and he will feel as though he had a wall to back up against; even though the woman be mentally a fool. (58)

Lawrence's implies that for a man to sustain contentment in his marriage, the desire for unity is fundamental. Through the construction of subjectivity based on life experiences and being practical, Tom has to conform to the unconventional masculine system. 
Lawrence correspondingly states that:

The vital desire of every woman is that she shall be clasped as axle to the hub of the man, that his motion shall portray her motionlessness, convey her static being into movement, complete and radiating out into infinity, starting from her stable eternality, and reaching eternity again, after having covered the whole of time. (Study of Thomas Hardy 56)

What is implied in the above extract is that a man is an actor, whereas a woman does not have to do anything. Simply being a woman she turns out to be the focus of a man's universe. Lawrence implies that a man's effort to negotiate his masculinity is important, as he is held accountable for the resolution in any conflicts. A man who is heterosexual will not feel fulfilled and can never attain his complete prospective without a woman to whom he can turn to. "Most men are usually purpose-driven and future-oriented". They are inclined to be rather oblivious to their surroundings and pay particular attentions to the society's needs. "They are deeply focused on doing, rather than on being" (Study of Thomas Hardy 56). Heterosexual men depend on women to build them to make life pleasant just like Tom's character.

Tom has to take discursive paths to work through his subordinate position in his effort to resist dominance and he could not achieve transformation without Lydia's help. In a positive relationship between a man and a woman, dominating one another results in failure as evident in Tom's marriage to Lydia. They did not surpass their conflicting point of views or dualism that exists within themselves, which was one of the essential idea emphasised by Lawrence. Lawrence implicitly writes a novel in which a man can act as if he exists as both a dominant social being and a person who resists dominant masculinity simultaneously. They can choose to live effectively in a position of negotiating, or they could survive in a world with no significance beyond the temporal world.

\section{Conclusion}

The analysis has led to the conclusion that there are moments in Tom's life when he realised that he is not required to perform the social principles of dominant masculine styles. The influence in the experience of household problems and subjectivity has enforced complicated feeling on the male protagonist, thereby initiating negotiation and resisting the dominant type of masculinity.

Tom in The Rainbow was a typical farm man doing courageous activities to develop his masculine nature but his lack of emotion and his refrainment from sharing his feeling with his wife put constraint in their relationship. However, Tom acknowledged his weaknesses and reconstructed himself to become a reasonable human being by negotiating his masculine identity.

\section{References}

Ben-Ephraim, G. (1981). The Moon's Dominion: Narrative Dichotomy and Female Dominance in Lawrence's Earlier Novels." Ed. Rutherford [N.J.]: London: Fairleigh Dickinson University Press.

Ben-Ephraim, G. (1981). The Moon's Dominion: Narrative Dichotomy and Female Dominance in Lawrence's Earlier Novels. Ed. Rutherford [N.J.]: London: Fairleigh Dickinson University Press.

Carter, Ph. (2001). Men and the Emergence of Polite Society, Britain 1660-1800. London: Longman, 2001. Print.

Johnson, A. G. (2005). The Gender Knot: Unraveling Our Patriarchal Legacy. Philadelphia, PA: Temple University Press, 2005. Print.

Lawrence, D H, and Bruce, S. (1985). Study of Thomas Hardy and Other Essays. Cambridge: Cambridge University Press.

---, The Rainbow. (1915). Harmondsworth: Penguin.

---, (1971). Fantasia of the Unconscious and Psychoanalysis and the Unconscious. Great Britain: Penguin Books.

Philip C. (2001). Men and the Emergence of Polite Society, Britain 1660-1800. London: Longman, 2001. Print.

Tosh, J. (1999). A Man's Place: Masculinity and the Middle Class Home in Victorian Britain. Harlow, London and New York: Pearson Longman.

Wetherell, M., and Edley, N. (1999). Negotiating Hegemonic Masculinity: Imaginary Positions and Psycho-Discursive Practices. Feminism \& Psychology, 9(3), 335-356. Print. 